\title{
Regulation of cell-mediated immunity in mice immunised with Salmonella enteritidis
}

\author{
ANNA GEORGE, ROHINI NAIR, S. RATH, S. N. GHOSH* and R. S. KAMAT† \\ Department of Immunology, Haffkine Institute, Parel, Bombay 400012 and *National Institute of Virology, \\ Pune, India
}

Summary. The effects of diverse factors, such as route of immunisation, composition of immunogen and administration of interferon inducer, on the expression of cellmediated immune responses against Salmonella enteritidis were investigated in BALB/c and Swiss white mice. Immunisation with live cells of $S$. enteritidis by the intraperitoneal route (ip) generated both delayed type hypersensitivity (DTH) and protective cell-mediated immunity (CMI). However, the two responses showed diametrically opposite time kinetics. The decline and disappearance by 9 weeks after ip immunisation of DTH and the rise of protective immunity in the same period suggested the possibility that the two responses were mediated by different subsets of $T$ cells. Immunisation by the intradermal (id) route with a sonicate of $S$. enteritidis generated only DTH; id immunisation also suppressed the development of the protective response following ip immunisation with live $S$. enteritidis. Both responses were not seen when $T$ cells were eliminated with anti-T cell serum. Oral immunisation with live cells of $S$. enteritidis induced excellent CMI expressing both DTH and protective responses. On the other hand, oral immunisation with the sonicate of $S$. enteritidis not only did not induce CMI, but also prevented the development of the DTH and protective response to ip immunisation with live $S$. enteritidis.

Induction of interferon by the administration of poly $\mathrm{I}$ : poly $\mathrm{C}$ for four consecutive days after id immunisation with killed $S$. enteritidis suppressed the generation of DTH.

\section{Introduction}

It is generally accepted that protection and recovery in systemic salmonella infections are brought about by cell-mediated rather than humoral immunity (Collins, 1974). However, various observations remain unexplained: first, in spite of extensive cross-antigenicity between ubiquitous environmental and pathogenic salmonellae (Tiwari and Kamat, 1986), natural immunity to enteric fever is not very prominent (Glynn, 1982); second, in certain individuals, infection leads to the development of a chronic carrier state (Dham and Thompson, 1982), which suggests that specific abnormalities in the immune response may exist; third, contradictory results concerning the efficacy of killed typhoid vaccines have been obtained from controlled field trials in man (Chuttani et al., 1971; Dupont et al., 1971) and from experiments in animals (Collins and Mackaness, 1968). These observations indicate that interactions between

Received 7 Feb. 1986; revised version accepted 31 Jul. 1986. $\uparrow$ Requests for offprints should be sent to Dr R. S. Kamat. bacterial antigens and the host need not necessarily be protective and bring into focus the importance of understanding the regulation of cellular immunity in salmonellosis.

In this report, we present evidence indicating that diverse factors such as the route of immunisation, nature of the immunogen and high levels of interferon modulate the cell-mediated immune response to salmonella antigens.

\section{Materials and methods}

\section{Bacteria}

Salmonella enteriditis (O 1, 9, 12 H 9, m; -) was isolated from a naturally infected mouse in the animal colony of Haffkine Institute, Bombay. Its rough mutant was obtained by serial culture of the smooth strain on nutrient agar.

\section{Mice}

BALB/c mice, 4-6 weeks old, obtained from the National Institute of Health, USA and maintained at the Cancer Research Institute, Bombay were used for studies in inbred animals. 
Swiss white mice, 4-6 weeks old, obtained from the National Institute of Health, USA and maintained in the animal colony of Haffkine Bio-Pharmaceutical Corporation Limited, Bombay, were used for studies in outbred animals. In all experiments 10 mice per group were used.

All mice were tested for delayed type hypersensitivity (DTH) to the sonicate of $S$. enteritidis before immunisation and adoptive cell transfer, and those showing no response were used. To prevent natural salmonella infection during experiments, the mice were maintained on food containing furazolidone $(250 \mathrm{mg} / \mathrm{kg}$ of food) and sterile water throughout the experiments in which soluble antigen or killed cells were used for immunisation, and from the second week after completion of immunisation in experiments in which live cells of $S$. enteritidis were used for immunisation.

\section{Sonicate antigen}

This was prepared by the method described by Collins and Mackaness (1968). An overnight culture of $S$. enteritidis on nutrient agar was suspended in phosphatebuffered saline(PBS), $p \mathrm{H} 7 \cdot 2$, killed by gamma irradiation (2.4 Mrad), washed in PBS and disrupted in a sonicator (Branson Sonic Power Co., USA). The sonicated material was centrifuged at $11000 \mathrm{~g}$ for $1 \mathrm{~h}$ to reduce its lipopolysaccharide content. The supernate was collected, filtered through a $0.45-\mu \mathrm{m}$ membrane filter (Millipore, USA), and termed "sonicate". The protein content of the sonicate was assayed by the method of Lowry et al. (1951) and appropriate adjustments made by dilution or concentration by vacuum dialysis.

\section{DTH response}

DTH was tested by the mouse foot-pad swelling technique of Gray and Jennings (1955). A 0.03-ml volume of sonicate containing $50 \mu \mathrm{g}$ of protein was injected into a hind foot-pad. Foot-pad thickness was measured before injection and $24 \mathrm{~h}$ and $48 \mathrm{~h}$ thereafter, with a dial gauge caliper (Mitutoyo, Japan). DTH was expressed as the corrected foot-pad enlargement (CPE), which is the difference between the mean 48-h foot-pad enlargements of test mice and non-immune controls tested simultaneously.

\section{Protective cell-mediated response}

Protection was assessed by the technique of Zinkernagel et al. (1977) with minor modifications. Briefly, it measured the ability of test mice to clear an intraperitoneal challenge of $600 \mathrm{cfu}$ of smooth $S$. enteritidis (100 LD50) compared with that of non-immune controls. The mice were killed on day 5 after challenge, and their spleens harvested aseptically and ground in sterile PBS. Appropriate dilutions of the lysate were plated on MacConkey's Agar and the number of salmonellae counted as cfu. A quantitative estimate of protective
CMI, expressed as the Protection Index (PI) was calculated by the following formula:

\section{Protection Index}

mean log cfu/spleen of control mice - mean log $\mathrm{cfu} / \mathrm{spleen}$ of test mice

$$
=\frac{\mathrm{cfu} / \mathrm{spleen} \text { of test mice }}{\text { mean } \log \mathrm{cfu} / \text { spleen of control mice }}
$$

The variance of the PI was calculated from the formula for variance of a ratio (Armitage, 1977).

\section{Adoptive syngeneic transfer}

Spleens of immunised mice were harvested and a cell suspension made in cold Hanks's Balanced Salt Solution (HBSS). The cell suspension was centrifuged and the pellet resuspended in HBSS containing $\mathrm{NH}_{4} \mathrm{Cl} 0.83 \%$ to lyse red cells. The cells were washed thrice, the viability estimated by trypan blue exclusion, and the requisite number of viable cells transferred to the recipient mouse by tail vein injection.

\section{Interferon levels in the serum}

These were assayed by employing the technique of inhibition of plaque formation by vesicular stomatitis virus as described by Merigan (1971).

\section{Depletion of T-cells}

$\mathrm{T}$ cells in mouse spleen cells were depleted by treatment with monoclonal anti-Thyl.2 antibody and complement, as reported earlier (George et al., 1986).

\section{Analysis of results}

All data were analysed by Student's $t$ test (Freund, 1967).

\section{Results}

\section{Regulation of DTH and protective CMI after intraperitoneal immunisation}

BALB/c mice were immunised intraperitoneally (ip) with $10^{5}$ cells of the rough mutant of $S$. enteritidis followed one week later with $10^{3}$ cells of the smooth strain, each suspended in $0.5 \mathrm{ml}$ of PBS. Their spleen cells were harvested 2, 4, 6 and 9 weeks after immunisation, and $4 \times 10^{7}$ cells adoptively transferred to naive, syngeneic mice which were then challenged to assay levels of DTH and protective CMI derived from effector T cells in the donor spleen-cell suspension. The results are shown in table I. A temporal dichotomy was observed 
Table I. Changes with time in levels of delayed type hypersensitivity, measured as corrected foot pad enlargement (CPE), and protective cell-mediated immunity, measured as the protection index (PI), after ip immunisation with $S$. enteriditis

\begin{tabular}{ccc}
$\begin{array}{c}\text { Time of transfer of immune } \\
\text { spleen cells (weeks after } \\
\text { immunisation) }\end{array}$ & CPE (mm)* & PI* \\
\hline 2 & $0.21 \pm 0.04$ & $0.14 \pm 0.03$ \\
$2^{\mathrm{a}}$ & $0.05 \pm 0.04$ & $0.05 \pm 0.02$ \\
4 & $0 \cdot 14 \pm 0.03$ & $0.31 \pm 0.09$ \\
9 & $0 \cdot 10 \pm 0.03$ & $0.40 \pm 0.16$ \\
9 & $0.00 \pm 0.03$ & $0.35 \pm 0.08$
\end{tabular}

* Results represent mean \pm SEM.

$2^{\mathrm{a}}=$ immune spleen cells with $\mathrm{T}$ cells selectively removed.

between the two responses. Whereas the mean CPE declined from $0.21 \pm 0.04 \mathrm{~mm}$ at 2 weeks to no response at 9 weeks, the mean PI increased from $0.14 \pm 0.03$ to $0.35 \pm 0.08$ in the same period.

Both responses were found to be T-cell mediated because treatment of the immune spleen cells with anti-Thyl. 2 antibody and complement before transfer prevented the expression of both responses in the recipient mice.



A

\section{Predominant generation of DTH response by} intradermal (id) immunisation with sonicate

BALB/c mice were immunised intradermally, bilaterally, in the flanks with $0.03 \mathrm{ml}$ of sonicate in an equal volume of complete Freund's adjuvant; three doses, containing $40 \mu \mathrm{g}, 80 \mu \mathrm{g}$ and $80 \mu \mathrm{g}$ of protein respectively, were given at 10 -day intervals. Two weeks later, their spleen cells were harvested, $4 \times 10^{7}$ cells transferred to naive, syngeneic mice and DTH and PI were assayed in the recipients. The DTH of the recipients, expressed as CPE, and protective CMI, expressed as PI, are shown in fig. 1A. Whereas the mean CPE of $0.34+0 \cdot 1 \mathrm{~mm}$ was significantly greater $(p<0.01)$ than that of nonimmune controls, the PI of $0 \cdot 23 \pm 0 \cdot 11$ was not, because of considerable variation between animals. The same figure also shows the DTH and protective CMI responses of mice that were recipients of immune spleen cells generated after live ip immunisation (fig. 1B), and similar T-depleted immune spleen cells (fig. 1C), for comparison. As we have already shown, immune spleen cells generated by ip immunisation effectively transferred both DTH and protective CMI, because the recipients, on being tested, showed a CPE of $0.21 \pm 0.04 \mathrm{~mm}$ and a PI of $0.14+0.03$ which were significantly greater than those of non-immune controls $(p<0.01)$ (fig.

B

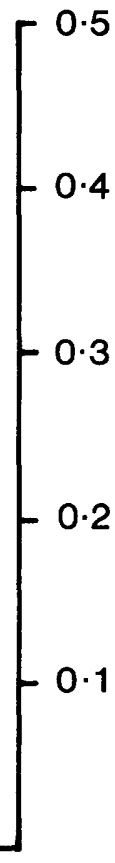

Fig. 1. Protection index $(\square)$ and delayed type hypersensitivity response $(\square)$ (mean $\pm S E M)$ in recipients of syngeneic spleen cells harvested: one week after id immunisation with sonicate of $S$. enteritidis (A); 2 weeks after ip immunisation with live $S$. enteritidis, the spleen cells being transferred without further treatment (B) or after depletion of $\mathrm{T}$ cells (C) (10 mice per group). 
1B). The recipients of $\mathrm{T}$-depleted immune spleen cells showed neither response (fig. 1C).

\section{Effect of splenic regulatory cells generated by} intradermal immunisation on the immunogenicity of live cells

BALB/c mice were immunised as before id with a sonicate of $S$. enteritidis. One week later, their spleen cells were harvested, $4 \times 10^{7}$ cells transferred to naive, syngeneic mice and the latter immunised ip with live $S$. enteritidis, a schedule known to generate effector $\mathrm{T}$ cells capable of mediating both DTH and protective CMI. One week after immunisation, spleen cells from these mice were transferred to a second set of syngeneic mice which were then challenged to assay levels of DTH and protective CMI. Whereas the mean CPE of the recipients was $0 \cdot 17 \pm 0.04 \mathrm{~mm}$ and was significantly greater than that of control mice $(p<0.01)$ the mean PI of $0.06 \pm 0.08$, was not (fig. $2 \mathrm{~A}$ ). The DTH and protective $\mathrm{CMI}$ responses of recipients of immune spleen cells generated after live ip immunisation (fig. 2B) and of similar T-depleted immune spleen cells (fig. 2C) are shown for comparison.

\section{Ability of a live, oral vaccine to generate the two responses}

BALB/c mice were fed $0.2 \mathrm{ml}$ of a suspension of live, smooth $S$. enteritidis in $0.9 \%$ saline, containing sodium bicarbonate $5 \%$. Four doses of $10^{3}, 0.25 \times$ $10^{4}, 1.3 \times 10^{5}$ and $6 \times 10^{7}$ live salmonellae were given at 4-day intervals. For confirmation of successful colonisation of the gut, faecal pellets of these mice were cultured in tetrathionate broth and salmonellae isolated on MacConkey's Agar. The isolates were confirmed to be $S$. enteritidis by standard bacteriological techniques (Edwards and Ewing, 1972). Two weeks after immunisation, their spleen cells were transferred into naive syngeneic mice to assay levels of DTH and protective CMI as before. The mean CPE of the recipients was $0 \cdot 14 \pm$ $0.04 \mathrm{~mm}$ and the mean PI was $0.42 \pm 0.08$ (both significantly greater, $p<0.01$ ), than those of nonimmune controls) (fig. 3A). The DTH and protective CMI responses of recipients of immune spleen cells generated after live ip immunisation (fig. 3B) and of similar T-depleted immune spleen cells (fig. $3 \mathrm{C})$ are shown for comparison.

\section{Generation of immunosuppression by oral immunisation with sonicate}

Swiss white mice were fed $0.2 \mathrm{ml}$ of sonicate containing $3.0 \mathrm{mg}$ of protein on the first three consecutive days of three consecutive weeks to induce tolerance to protein antigens (Chase, 1959). The mice were rested for a week and then tested for DTH to $S$. enteritidis antigens. None of the mice showed a DTH response. They were then immu-

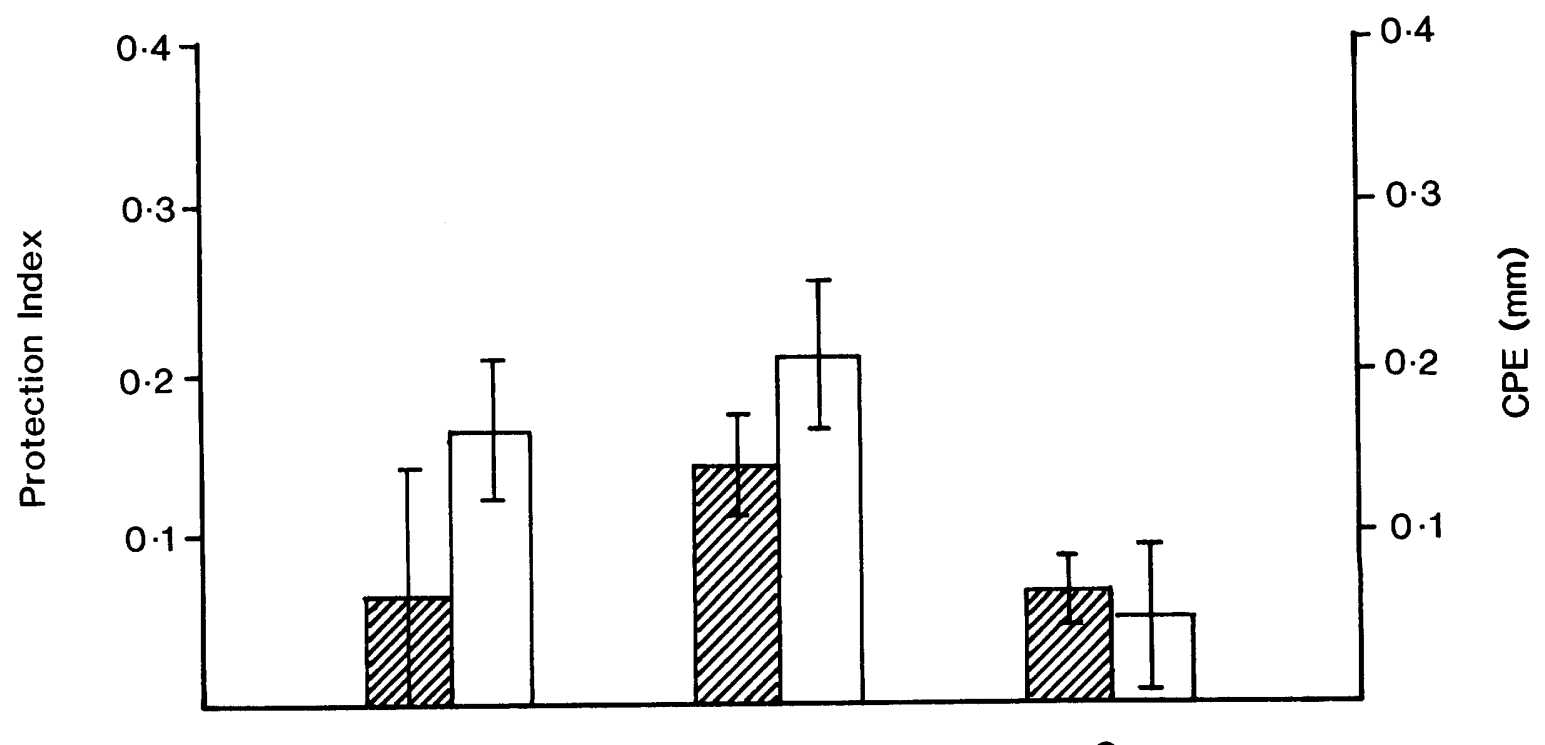

A

B

C

Fig. 2. Protection index $(\square)$ and delayed type hypersensitivity $(\square)$ (mean \pm SEM) in recipients of immune spleen cells harvested 2 weeks after ip immunisation with live $S$. enteritidis: of mice which were also recipients, before immunisation, of spleen cells harvested 2 weeks after id immunisation with sonicate of $S$. enteritidis (A); of mice with no such pretreatment and cells transferred without further treatment (B) or after depletion of T cells (C). 
nised with live $S$. enteritidis ip, as before, and tested for the development of DTH a week later. Five out of eight mice showed a good DTH response with a mean CPE of $0.50 \pm 0.09 \mathrm{~mm}$. The remaining three mice showed no DTH response.

These results were interpreted as suggesting that oral antigenic stimulation was, perhaps, capable of suppressing the response to subsequent immunisation by the ip route with live cells. Because of considerable variation between animals this was further investigated in a syngeneic system. BALB/c mice were fed with sonicate as before and rested for a week. They were then tested for DTH and found to show no reaction. Spleen cells from these mice were harvested and $4 \times 10^{7}$ cells transferred into naive, syngeneic mice which were then immunised ip with live $S$. enteritidis, which is known to generate both DTH and protective CMI. Two weeks after immunisation their spleen celis were transferred to a fresh set of syngeneic mice and the levels of DTH and protective CMI assayed as before. Neither DTH nor CMI could be transferred.
The mean CPE of the recipients was $0.02 \pm$ $0.02 \mathrm{~mm}$ and the PI was $0.003 \pm 0.02$, both responses being not significantly different from those of non-immune controls (fig. 4A). The DTH and protective CMI responses of recipients of immune spleen cells generated after live ip immunisation (fig. 4B) and similar T-depleted immune spleen cells (fig. 4C) are shown for comparison.

\section{Interferon (IFN)-mediated suppression of CMI}

Swiss white mice were immunised id with $0.05 \mathrm{ml}$ of a suspension containing $10^{9}$ killed cells of $S$. enteritidis in PBS. The mice were then divided into two groups. One group was maintained without further treatment and the other group was treated with $100 \mu \mathrm{g}$ of polyinosinic acid polycytidylic acid (poly I:poly C; Sigma, USA) intravenously, $21 \mathrm{~h}$ after immunisation. This was followed by three injections, each of $10 \mu \mathrm{g}$, at 24-h intervals. Control mice were treated with identical doses of poly I: poly $\mathrm{C}$, a representative number were bled out at

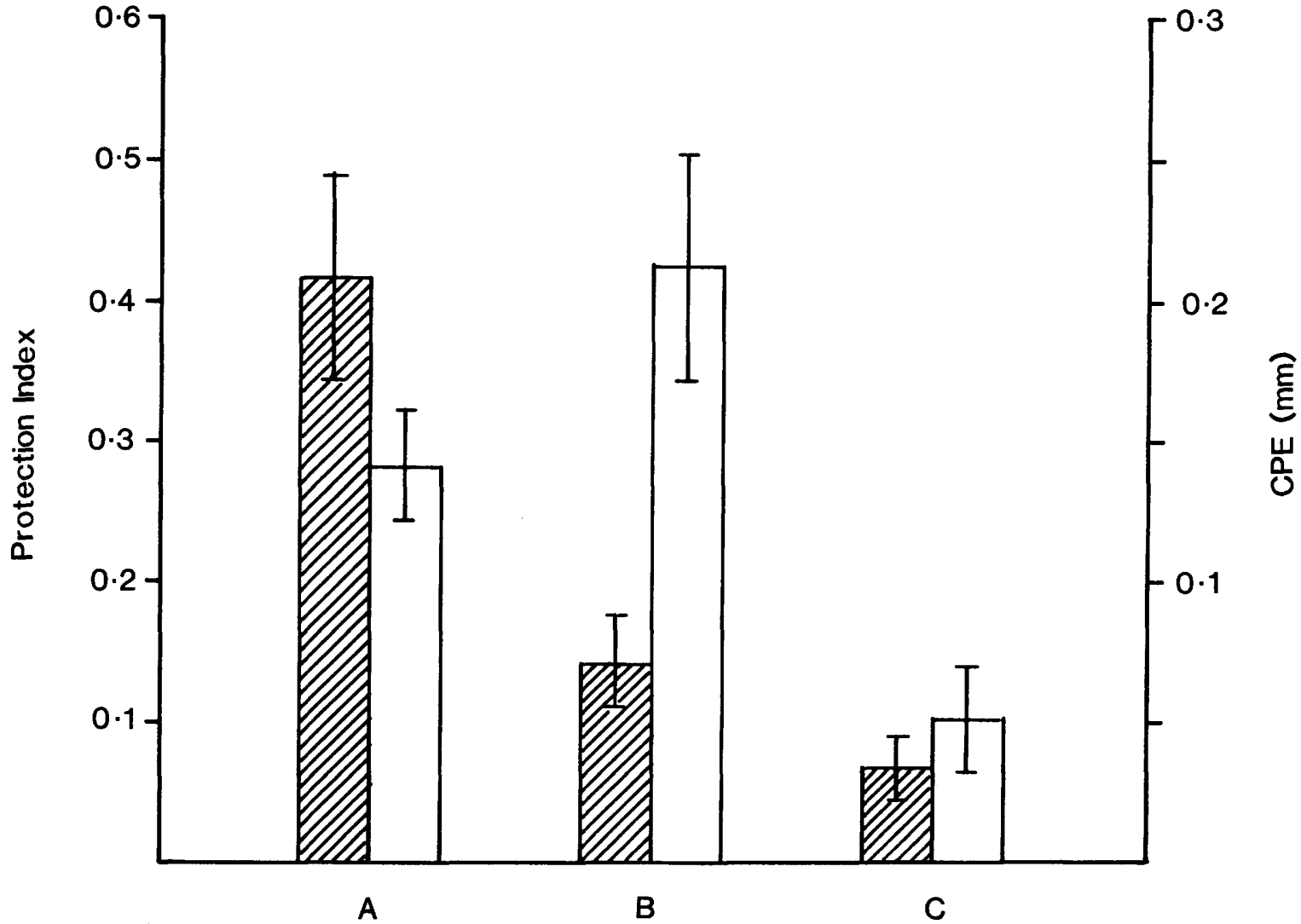

Fig. 3. Protection index $(\mathbb{Z})$ and delayed type hypersensitivity $(\square)($ mean $+S E M)$ in recipients of syngeneic spleen cells harvested 2 weeks after: oral immunisation with live $S$. enteritidis (A); ip immunisation with live $S$. enteritidis, cells being transferred without further treatment (B) or after depletion of T cells (C). 




Fig. 4. Protection index $(\mathbb{Z})$ and delayed type hypersensitivity $(\square)$ (mean \pm SEM) in recipients of syngeneic spleen cells harvested 2 weeks after ip immunisation with live $S$. enteritidis: of mice who were also recipients, before immunisation, of syngeneic spleen cells of mice who were fed sonicate of $S$. enteritidis (A); of mice without such pretreatment, the cells being transferred untreated (B) or after depletion of $\mathrm{T}$ cells $(\mathrm{C})$.

different times and serum IFN levels assayed to confirm that they were raised (table II).

The mice were tested for DTH one week after immunisation and their responses compared with those of non-immune controls. Mice immunised with killed cells alone showed a mean CPE of $0.25 \mathrm{~mm}$. In contrast, mice treated with poly I: poly $\mathrm{C}$ after immunisation showed a mean CPE of $0.07 \mathrm{~mm}$ (table III). The difference was statistically significant $(\mathrm{p}<0 \cdot 05)$.

\section{Discussion}

The data presented in this paper establish very clearly that the outcome of immunisation with salmonella depends on the nature of the bacterial

Table II. Serum interferon levels in mice after poly I: poly $\mathrm{C}$ administration

\begin{tabular}{lcc}
\hline \multicolumn{1}{c}{ Treatment } & $\begin{array}{c}\text { Assay time after } \\
\text { treatment }\end{array}$ & $\begin{array}{c}\text { Mean interferon } \\
\text { levels } \\
(\mathrm{IU} / \mathrm{ml})\end{array}$ \\
\hline $100 \mu \mathrm{g}$ polyI : poly C & $3 \mathrm{~h}$ & $906 \pm 371 \cdot 6^{*}$ \\
$\begin{array}{l}10 \mu \mathrm{g} \text { poly I: poly C } \\
3 \text { doses of } 10 \mu \mathrm{g} \text { of polyI: } \\
\text { poly C at } 24 \text { - } \mathrm{h} \text { intervals }\end{array}$ & $24 \mathrm{~h}$ & $19 \cdot 13 \pm 3 \cdot 71^{*}$ \\
\hline
\end{tabular}

* SEM of 5 samples.
Table III. Suppression in mice by interferon of delayed type hypersensitivity, measured as corrected foot pad enlargement (CPE), to salmonella antigen

\begin{tabular}{ccc}
\hline Immunogen & $\begin{array}{c}\text { Poly I:poly C } \\
\text { treatment }\end{array}$ & $\begin{array}{c}\text { Mean CPE } \\
(\mathrm{mm})( \pm \text { SEM })\end{array}$ \\
\hline $10^{9}$ killed $S$. enteritidis $(\mathrm{id})$ & No & $0 \cdot 25 \pm 0.05$ \\
$10^{9}$ killed $S$. enteritidis (id) & Yes & $0.07 \pm 0.04$ \\
\hline
\end{tabular}

antigen and on the route of administration. Immunisation with live cells by the ip route generated the two important effector responses of CMI-DTH and protection. However, it was clear that whereas the former declined with time, the latter increased. We have further shown in a recent report that such ip immunisation generates suppressor cells which preferentially suppress DTH (George et al., 1986). Immunisation with killed cells ip generates neither DTH nor protective CMI (Khedkar et al., 1982).

Intradermal immunisation with sonicate selectively generated DTH. Moreover, this mode of immunisation generated suppressors that selectively suppressed the generation of protective CMI in response to a subsequent ip immunisation with live $S$. enteritidis.

From the above results we conclude that DTH and protection are differentially regulated, showing 
different time kinetics and susceptibilities to suppression. The data presented in this paper indicate that id immunisation with sonicate generates cells which specifically suppress protective CMI while in an earlier paper (George et al., 1986) we have shown that ip immunisation with live cells generates suppressors specifically directed at DTH. Hence, it appears that suppressor cells generated by ip and id immunisation have different $\mathrm{T}$-cell subsets as targets. These different responses related to the route of immunisation may be a reflection of the fact that the skin and peritoneal cavity possess different antigen-presenting cells (APC). Katz (1984) reported that different differentiation pathways for T cells are a function of the APC types presenting a complex bacterial antigen. Whether they are due to the reported differences in the Ia composition of APC cells (Cowing et al., 1978) is a matter open to conjecture.

The two sets of experiments with oral immunisation seem to contradict each other. Whereas live cells induced protection, the sonicate not only failed to immunise but also generated suppressor cells that could cut off both responses. This apparent controversy can be reconciled if one takes into account the fact that salmonellae are invasive pathogens so that live cells given orally may penetrate the gut to local lymph nodes, thus circumventing the suppressive mechanisms of the gut which have been reported by Mattingly and Waksman (1976).

The data reported in this paper also have

\section{REFERENCES}

Armitage P 1971 Statistical Methods in Medical Research, Blackwell Scientific Publications, Oxford, p 97.

Chase M W 1959 Immunological tolerance. Annual Review of Microbiology 13 : 349-376.

Chuttani C S, Prakash K, Verghese A, Sharma U, Singha P, Ray B G 1971 Effectiveness of oral killed typhoid vaccine. Bulletin of the World Health Organization 45: 445-450.

Collins F M 1974 Vaccines and cell mediated immunity. Bacteriological Reviews 38: 371-402.

Collins F M, Mackaness G B 1968 Delayed hypersensitivity and Arthus reactivity in relation to host resistance in Salmonellainfected mice. Journal of Immunology 101 : 830 -845.

Cowing C, Schwartz B D, Dickler H B 1978 Macrophage Ia antigens. I. Macrophage populations differ in their expression of Ia antigens. Journal of Immunology 120: 378-384.

Dham S K, Thompson R A 1982 Humoral and cell mediated immune responses in chronic typhoid carriers. Clinical and Experimental Immunology $50: 34-40$.

Dupont H L, Hornick R B, Snyder M J, Dawkins A T, Heiner G G, Woodward T E 1971 Studies of immunity in typhoid fever. Protection induced by killed oral antigens or by primary infection. Bulletin of the World Health Organization 44: $667-672$. important clinical implications. Because CMI is so important in salmonellosis, the obvious limitations of killed vaccines given by different routes are highly significant. Similarly, in conditions such as septicaemia, the diverse APC encountering the antigen might drive $\mathrm{T}$-cell differentiation in an unpredictable manner. Moreover, in communities where zoonotic and environmental salmonellae are very common, contamination of water and food might have definite but unpredictable effects on Tcell immunity to salmonellae, depending upon whether the contaminating agent were live or dead. We have recently reported that, when CMI responses are measured, cross-reactions between zoonotic and environmental salmonellae and those salmonellae that cause enteric fever are extensive (Tiwari and Kamat, 1986). Natural infections need not necessarily enhance host immunity. Similarly, in chronic carrier states with infection persisting in the gall bladder, the antigen excreted into the intestines might effectively suppress host CMI.

The suppressive effects of interferon on T-cell differentiation, so clearly demonstrated in this report, have some important implications for susceptibility to bacterial infections in relation to concomitant viral infections.

Monoclonal anti Thy-1.2 antibody was kindly supplied by Dr N. A. Mitchison of University College, London.

A.G. thanks the Indian Council of Medical Research for a fellowship grant to undertake this study.

Edwards P R, Ewing W H 1972 Identification of Enterobacteriaceae, 3rd edn. Burgess Publishing Co., Minneapolis, p 146.

Freund J 1967 Modern elementary statistics, 3rd edn. Prentice Hall, New York, p 256.

George A, Rath S, Kamat R S 1986 Differential regulation of effector responses of cell mediated immunity in experimental Salmonellosis. Clinical and Experimental Immunology 63 : 327-333.

Glynn A A 1982 Vaccines versus bacterial disease. In: Lachmann P J, Peters D K (eds) Clinical aspects of immunology, 4th edn, vol 2. Blackwell Scientific, Oxford, pp 1465-1481.

Gray D E, Jennings P A 1955 Allergy in experimental mouse tuberculosis. American Review of Tuberculosis 72: 171-195.

Katz D R 1984 Differences in accessory cell functions. Immunobiology 168 : 134-140.

Khedkar S, Sharma K D, Kamat R S 1982 Relative importance of humoral and cellular immune responses in experimental Salmonella enteritidis infection. Indian Journal of Medical Research 76: 65-71.

Lowry O H, Rosebrough N J, Farr A L, Randall R J 1951 Protein measurement with the folin phenol reagent. Journal of Biological Chemistry 193: 265-275.

Mattingly J A, Waksman B H 1976 Immunologic suppression after oral administration of antigen I. Specific suppressor 
cells formed in rat Peyer's patches after oral administration of SRBC and their systemic migration. Journal of Immunology 121 : 1878-1883.

Merigan T C 1971 A plaque inhibition assay for human interferon employing human neonate skin fibroblast monolayers and bovine vesicular stomatitis virus. In: Bloom B $\mathrm{R}$, Glade $\mathrm{P} \mathbf{R}$ (eds) In vitro methods in cell mediated immunity. Academic Press, pp 489-500.
Tiwari H, Kamat R S 1986 Cross reactions in cell mediated immunity of enteric fever causing Salmonella. Journal of Medical Microbiology 21 : 233-237.

Zinkernagel R M et al. 1977 . H-2 restriction of cell mediated immunity to an intracellular bacterium. Effector $\mathrm{T}$ cells are specific for Listeria antigen in association with $\mathrm{H}-2 \mathrm{I}$ region coded self markers. Journal of Experimental Medicine 145: 1353-1367. 